\title{
Integrated Subsurface Analysis of Thickness and Density for Liquefaction Hazard: Case Study of South Cilacap Region, Indonesia.
}

\author{
Maulana Rizki Aditama', Huzaely Latief Sunan', FX Anjar Tri Laksono', Gumilar \\ Ramadhan $^{1}$, Sachrul Iswahyudi ${ }^{12}$, Fadlin ${ }^{1,3}$. \\ ${ }^{1}$ Department of Geological Engineering, Universitas Jenderal Soedirman, Purwokerto, Central Java, Indonesia. \\ ${ }^{2}$ Department of Geological Engineering, Universitas Padjajaran, Bandung, Indonesia. \\ ${ }^{3}$ Petrology and Geological Laboratory, Akita University, Akita City, Japan.
}

* Corresponding author : maulanarizkia@unsoed.ac.id

Tel: +6282136227703

Received: Nov 24, 2020; Accepted: March 26, 2021

DOI : 10.25299/jgeet.2021.6.1.5892

\begin{abstract}
The thickness of the liquefable layer can be the factor inducing liquefaction hazard, apart from seismicity. Several studies have been conducted to predict the possibility of the liquefable layer based on the filed sampling. However, a detailed investigation of the subsurface interpretation has not been defined, in particular the thickness estimation of the liquefable layer. This study is carried out in south Cilacap area where potential liquefaction is exists due to the earthquake history data and near surface condition. The aim of this study is to investigate the physical properties and thickness distribution using GGMplus gravity data and resistivity data. This research is conducted by spectrum analysis of gravity model and 2D resistivity model. This study's main results is by performing the residual gravity anomaly with the associated SRTM/DEM data to define the subsurface physical distribution and structural orientation of the area. Residual gravity anomaly is also separated through the low pass filter in order to have robust interpretation. The residual anomaly indicates that the area has identical structural pattern with geological and SRTM map. The results show a pattern of high gravity index in the northeast area of the study having range of $70-115$ MGal gravity index, associated with the volcanic breccia, and a low gravity profile with less than 65 in the southwest, associated with the alluvial and water table dominated distribution. The thickness of Alluvial is determined by resistivity model with $\mathrm{H} 1$ at a range of 3 meters and $\mathrm{H} 2$ at a range of $4 \mathrm{~m}$. This research is included in the potential liquefaction category with the potential for a large earthquake.
\end{abstract}

Keywords: residual anomaly, physical properties, gravity acceleration, subsurface interpretation

\section{Introduction}

Liquefaction is a phenomenon of loss of soil shear strength in water-saturated sand due to earthquake vibrations. This event causes the soil to collapse and behave like a liquid (Aditama et al., 2020). In general, the liquefaction phenomenon occurs in granular of sand layers that are saturated with water and receive cyclic loads due to the earthquakes (Jinguuji and Toprak, 2017). Earthquake vibrations cause soil particles to contract, and swiftly become undrained conditions (Pokhrel et al., 2013). When the pore water pressure value is equal to the total soil stress, effective soil stress is zero, resulting in a decrease of shear strength and collapses (Hardy et al., 2015). One way to determine the potential danger of liquefaction is by determining the subsurface conditions such as the lithology, physical property and thickness of water table layer (Muhaimin et al., 2016) (Ozcep and Ozcep, 2011). This research is carried out in south Cilacap where the seismicity is potentially high, supported by the prone of alluvial deposition distributed across the southern area (Suwarno et al., 2019). 
Regional geology refers to previous research on the Geological Map of Pangandaran Sheet (Van Bemmelen, 1949). Based on the Figure 1C, the stratigraphical unit consists of the Quaternary Deposits (Qa), the Kumbang Formation (Tpks), the Halang Formation (Tmph), and the Fm Halang Sandstone Members (Tmhs). Most of the resistivity data samples are taken from the alluvial (Qa) deposits in the southern area (Van Bemmelen, 1949).

The north western part consists of settlements, rice fields, industry, and others. This area can be said to be a developing area with the support of several factors such as the large population, the times, and the fairly flat topography so that development in this area is also developing (Gao, Chen and Luo, 2013). To support this development, technical information, especially subsurface engineering geology is needed so that the development and development of the area can be sustained (Iswahyudi et al., 2019). The purpose of this research is to determine the physical properties of rock distribution and the thickness area of liquefable layer through the resistivity model (Aditama et al., 2019). This result is then projected into the Jingunji model to compare the relevance of liquefable layer into the potential earthquake (Jinguuji and Toprak, 2017).

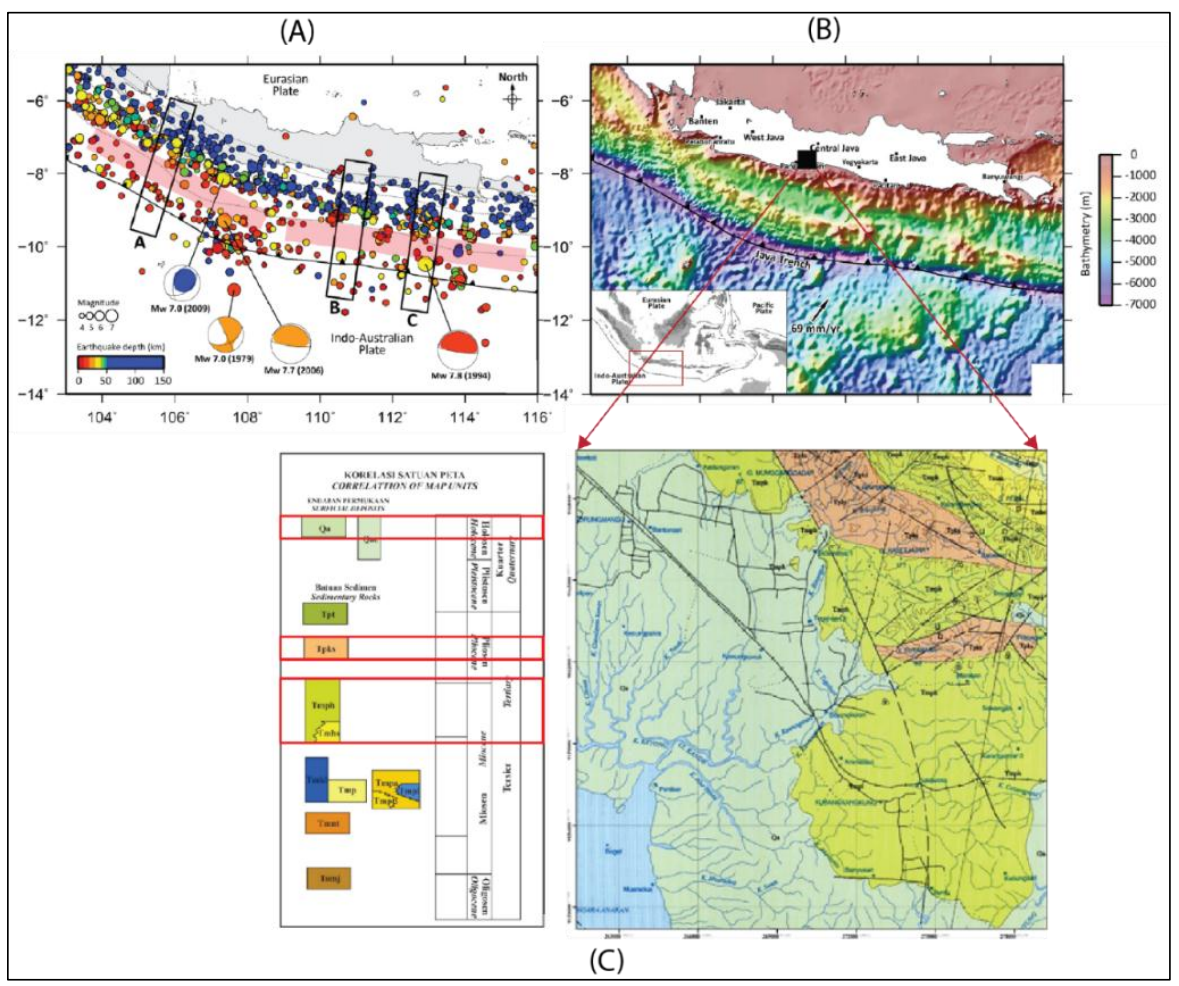

Fig.1. (A) The epicentre relocated distribution map distribution of the South Java trench as potential trigger for ground movement which could affect the liquefaction risks, followed by figure B as the most likely shallow bathimetry map (Widiyantoro et al., 2020). (C) Research location, situated in south cilacap regency with $400 \mathrm{~km}^{2}(20 \mathrm{~km} \times 20 \mathrm{~km})$, specifically in $9150000 \mathrm{mN}-9170000 \mathrm{mN}$, and $260000 \mathrm{mE}-280000 \mathrm{mE}$. The research location is mainly dominated by alluvial distribution of quartenery deposits.

\section{Material and Method}

\subsection{Gravity data}

Gravity is acquired using the extraction of satellite data, EGM 2008, overlain by the short scale of topography effect (Hirt et al., 2013). We used 2 out of 4 GGMplus satellite data source, which are (i) Gravity Acceleration, and (ii) Free air anomaly based on the spectrum analysis (Masson et al., 2012). The

$$
C_{B}=2 . \pi \cdot G . \rho \cdot \mathrm{h}_{p}
$$

Spectrum analysis is a Fourier transform process to convert a signal into the sum of several sinusoidal signals with various frequencies (Hall, 2012). Free fall acceleration and the Gravity anomaly to approach the number of elevations is defined on the following equation [Eq.1; Eq.2]

$$
\triangle g_{S B}=\Delta g_{D}-C_{B}
$$


Where $C_{B}$ is bouger correction, $G$ is gravity acceleration of earth (constant value), $\rho$ is density, and $h$ is the variability of elevations. Following the first equation [Eq.1], the correction is needed to yield Simple bouger anomaly (SBA) (Fitz Gerald, 2020). The correction is then explained on second equation [Eq.2] with the reduction between $\Delta g_{S B}$ gravity disturbance from GGMPlus dataset and the bouger correction (Zeng, Xu and Tan, 2007 ; Guillen et al., 2008).

The result highlights an amplitude spectrum and a phase spectrum which is used to estimate the depth of anomaly by estimating the value of the wave number ( $\mathrm{k}$ ) and amplitude (A). This can be used to calculate the width of the filter window which is then used as data input in the filtering process, separation of regional anomalies, and residual anomalies (Zeng, Xu and Tan, 2007). In addition, plot of $\ln A$ against $k$, divided from six-track slicing. It can be seen in the graph that $\ln \mathrm{A}$ against $\mathrm{k}$ in the spectrum analysis will experience a reflection of the whole data plot (Figure 2) (Masson et al., 2012) . Then on the graph there are red and blue colors, red color represents regional anomalies and blue color represents residual anomalies (Figure 2).

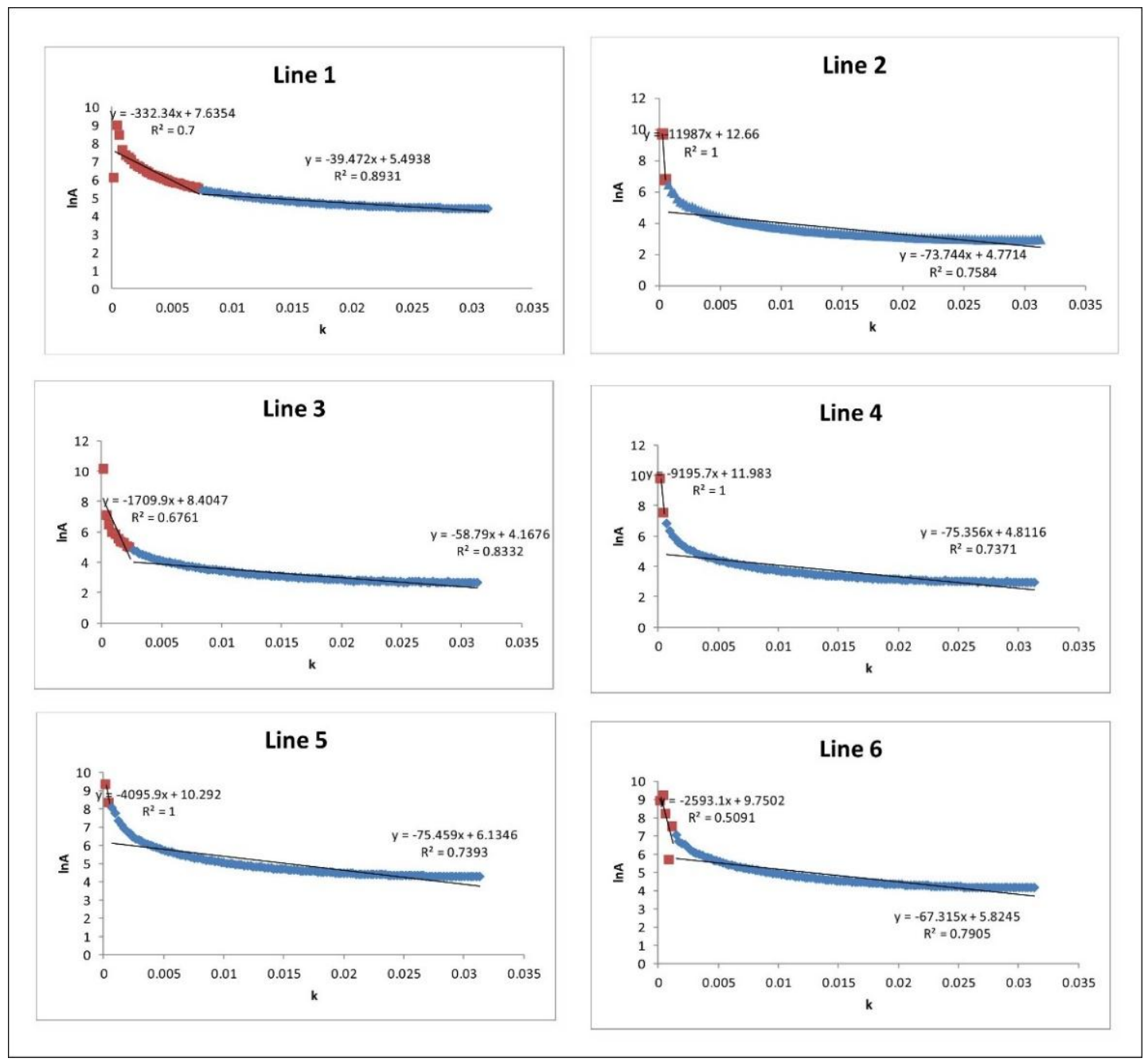

Fig. 2. Six different spectrum analysis is plotted with wave number and amplitude. The graph shows two different colors representing the regional depth and residual depth through red and blue colors, respectively. Those depth will inform the gravity anomaly from the residual data interpolation. 
Table 1. Six line shows different regional and residual depth, ranging from $39 \mathrm{~km}$ to $75 \mathrm{~km}$ of depth. This data is important to get a robust interpretation of gravity anomaly

\begin{tabular}{cccccccc}
\hline Line & $\begin{array}{c}\text { Regional } \\
\text { Depth }\end{array}$ & $\begin{array}{c}\text { Residual } \\
\text { Depth }\end{array}$ & $\mathrm{C} 1$ & $\mathrm{C} 2$ & $\mathrm{X}$ (k cutoff) & Lamda & $\mathrm{N}$ \\
\hline 1 & $-332,34$ & $-39,472$ & 7,6354 & 5,4938 & 0,007312509 & 859,237913 & 3,43695165 \\
2 & -11987 & $-73,744$ & 12,66 & 4,7714 & 0,00066217 & 9488,78065 & 37,9551226 \\
3 & $-1709,9$ & $-58,79$ & 8,4047 & 4,1676 & 0,002566213 & 2448,42701 & 9,79370805 \\
4 & $-9195,7$ & $-75,356$ & 11,983 & 4,8116 & 0,000786308 & 7990,74259 & 31,9629704 \\
5 & $-4095,9$ & $-75,459$ & 10,292 & 6,1346 & 0,001034066 & 6076,19566 & 24,3047826 \\
6 & $-2593,1$ & $-67,315$ & 9,7502 & 5,8245 & 0,001554249 & 4042,58481 & 16,1703393 \\
\hline
\end{tabular}

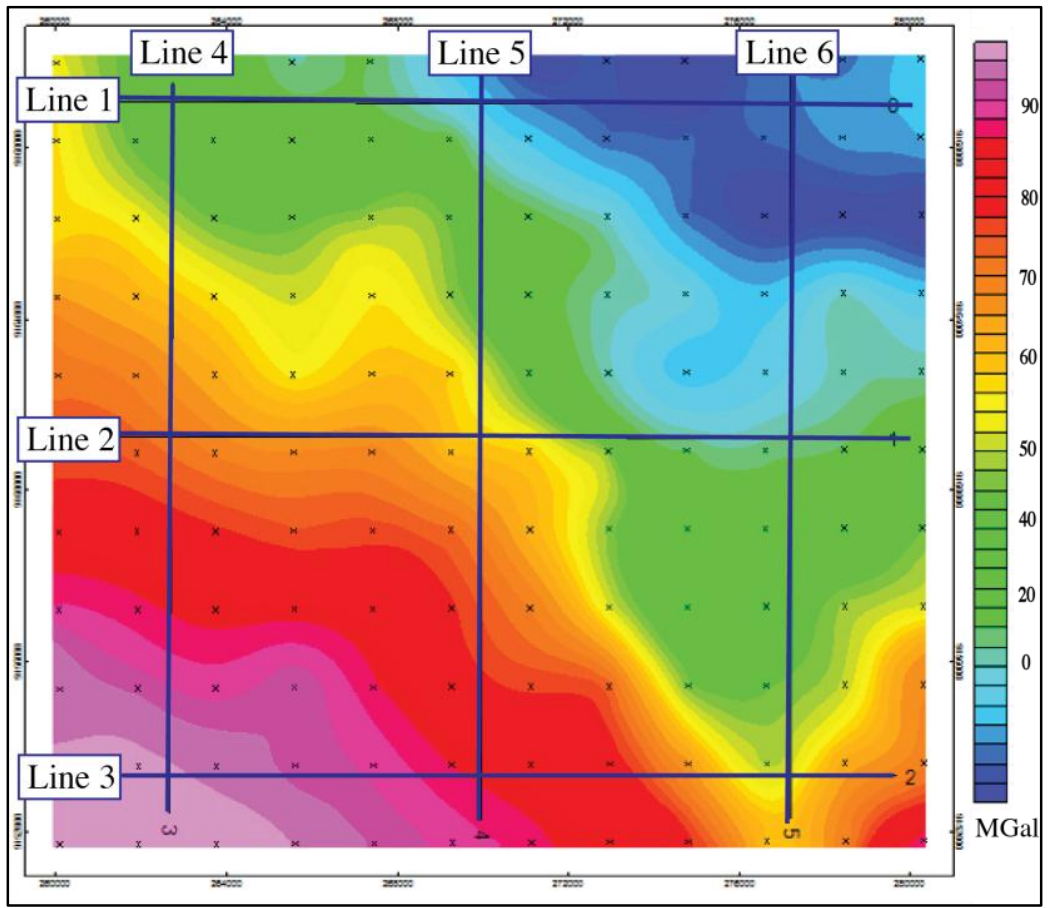

Fig. 3. 2D residual map based on the spectrum lines. It shows the residual anomaly in lateral distribution of data. This map is one of important steps to understand the physical property of density in subsurface area.

The spectrum analysis and each gravity data point are then projected into the 2D map model to generate the residual anomaly map distribution (Figure 3). The residual anomaly of gravity will be combined with the Digital Elevation Model type

\subsection{Resistivity Data}

Resistivity data use Schlumberger configuration plotted in 3 different locations (Figure 4). All data obtained will be modeled using Progress 3.0 software to determine $1 \mathrm{D}$ resistivity plot against the distance (Tini et al., 2017). This software also
SRTM V.4.1 1 to determine the topography of the peripheral area's topography (Nakata and Snieder, 2014). The main interpretation will be the combination between residual anomaly and the Digital Elevation Model.

uses a forward modeling method to obtain resistivity and depth profiles. The resistivity profile shows the estimation of subsurface layers vertically including the resistivity value and the depth of each layer at the sounding point (Hirt et al., 2013). 


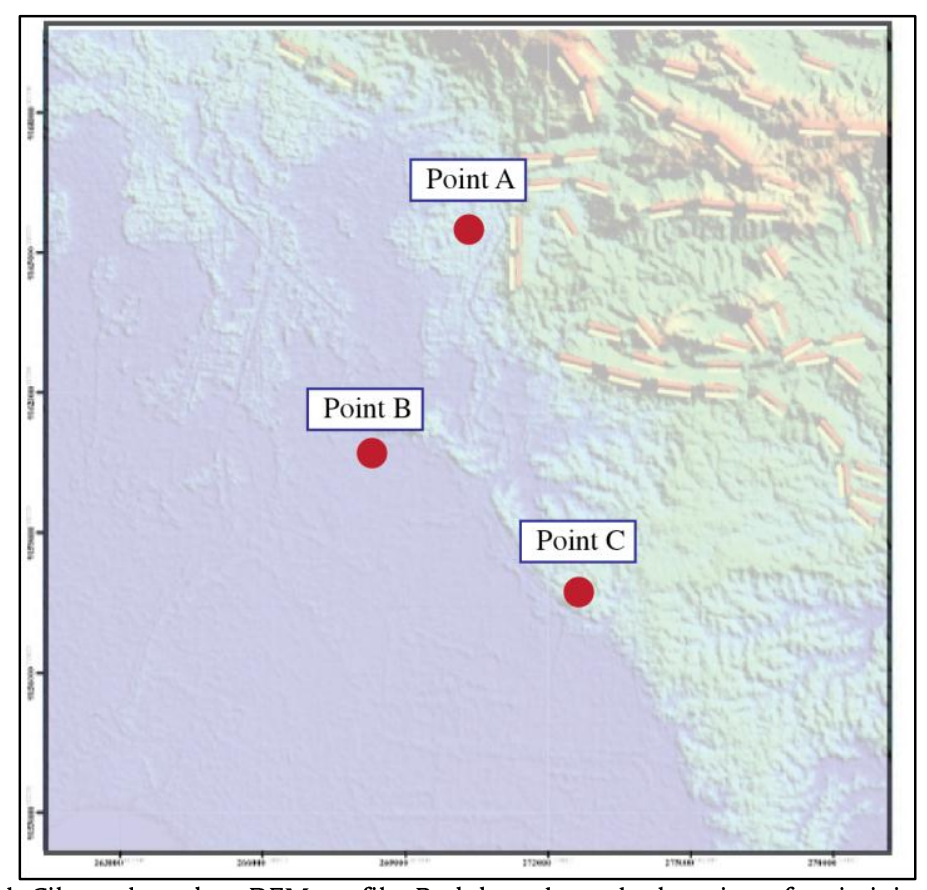

Fig 4. Research map of south Cilacap based on DEM profile. Red dots show the location of resistivity acquisition data, separated within the northern and southern area. The separate location is important to generate correlation of lithology for liquefable layer.

In order to generate 2D profiles, we use Res2dinv version 3.54.44. Res2dinv will automatically generate a $2 \mathrm{D}$ or $3 \mathrm{D}$ subsurface resistivity model from data processing based on geoelectric tomography measurements (Daud et al., 2019). The resistivity model generated by Res2dinv is a model resulting from the inversion of field measurement data in the form of apparent resistivity

\section{Result and Discussion}

\subsection{Lateral distribution of bouger anomaly}

The lateral density distribution is constructed using residual gravity anomaly. It shows that most of the residual anomaly has relatively shallow deflection of subsurface rock, as the anomaly ranging from $20 \mathrm{MGal}$ to $120 \mathrm{MGal}$. This range creates a variability of gradient and contour straightness in the northeast area, presumably as a result of the large number of fault structures with $115 \mathrm{MGal}$ bordering with very low anomaly at $45 \mathrm{MGal}$ (Figure 5).

Most of low gravity anomalies are distributed in the south and southwest of area. In this area, major fault indication is less, but potentially small-scale fault is existing. Since low gravity is presence, the to obtain the actual value in the form of a subsurface section below the measurement data. Before a subsurface resistivity model of a measurement path is formed, several data processing processes are carried out on Res2dinv, where the Res2dinv software is set with the default setting and the inversion result model (pseudosection) is created with five iteration processes.

area is dominated by the distribution of alluvial sediments with $55 \mathrm{MGal}$ - $60 \mathrm{MGal}$, having low basement thickness due to high gravity anomalies (Figure 6).

This is potentially interpreted as alkaline crustal rocks of the Ocean, lies beneath the Miocene section. Based on the topography, the northeast part has a high topography compared to other areas, thus indicating a homogeneous type of lithology or a uniform level of rock resistance to erosion and weathering. The interpretation of the area is volcanic breccia lithology based on correlation with regional geological maps (Figure 6). 


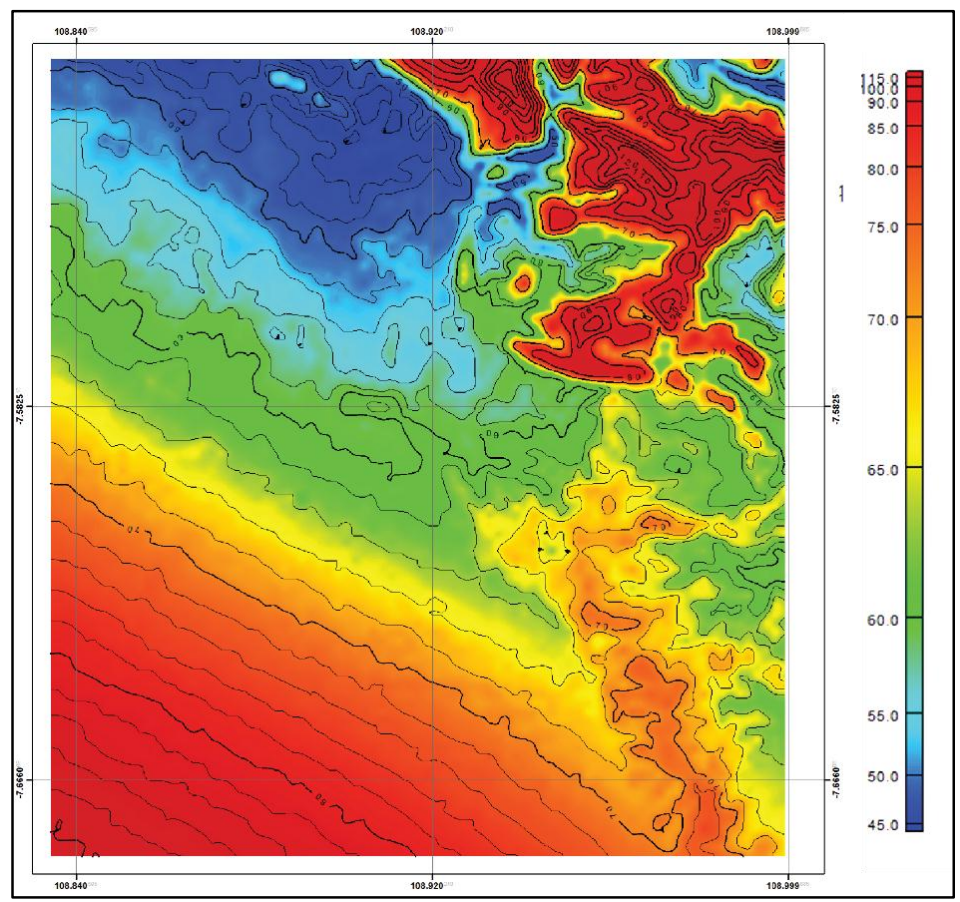

Fig. 5. Residual anomaly map demonstrates the distribution of physical properties and potential gap of basement to tertiary (alluvial) formation. The anomaly rises at the northeast due to the potential high topography, in-line with the local basement uplift. It is the decrease toward Centre and western area as most of the area has no indication of fault and thickness of sediments are arises.

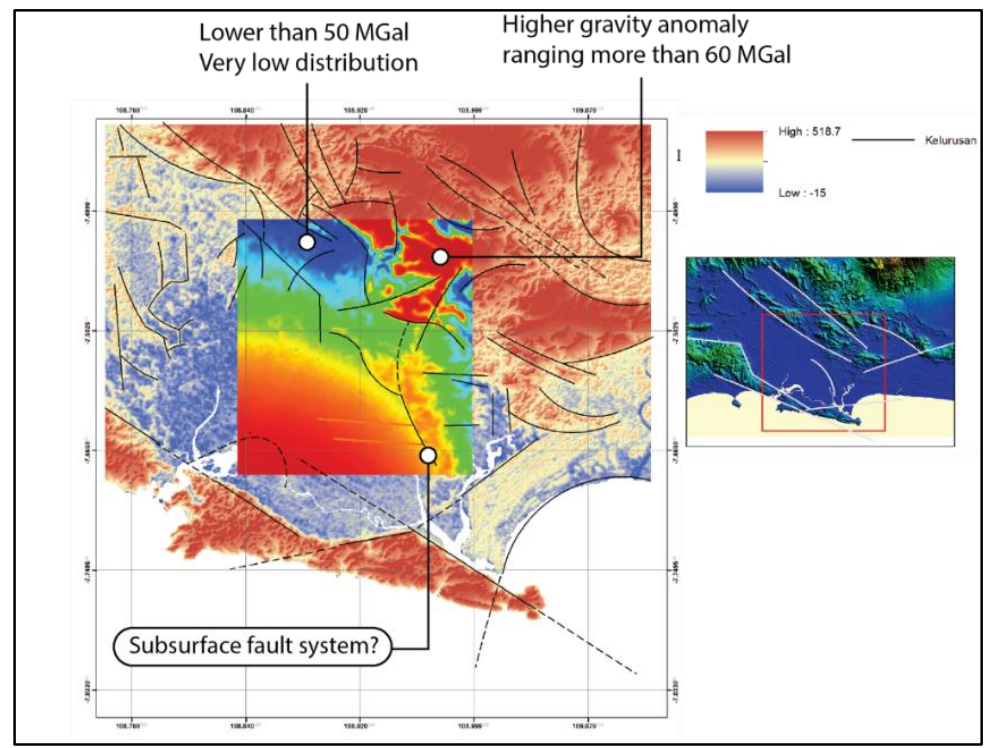

Fig. 6. Residual anomaly to DEM profile is used to delineate the structural context with the lateral distribution. Generally, major fault scales in the north are correlated with residual anomaly, whereas low anomaly is determined as low topography in the south west area. Small scale fault appears in the centre and north-west area, having 1000-2000 m in strike direction.

\subsection{Near-surface thickness from resistivity data.}

Near surface liquefaction thickness is determined by the lithological correlation through the resistivity plot. All resistivity lines have $85 \mathrm{~m}$ of length and $2.5 \mathrm{~m}$ distances between its electrodes. 2D resistivity model is plotted based on resistivity anomaly of subsurface which has variation of depths between $7.97-11 \mathrm{~m}$.

Point A has resistivity values from 3.57-68.7 70, formed predominantly by alluvial deposits $(\mathrm{Q} a)$ at a thickness of 1- 9 meters. Point A has low resistivity 
zone with 3.57-12.7 $\Omega \mathrm{m}$, representing the watersaturated alluvial layer and detected at a depth of 4.63- $7.97 \mathrm{~m}$ below the surface (Figure 7). Point B has a range of resistivity values from 3.09-74 $\Omega \mathrm{m}$ with an error presentation of $0.94 \%$ in the 10 th iteration. Alluvial were detected at a depth of 0.625-4.63 m below the surface, with low resistivities between 3 $9 \Omega \mathrm{m}$. This low value is in accordance with the observation at point $A$ where the alluvial is dominated by water (Figure 7).
Point $\mathrm{C}$ stuated around the settlement, this is in accordance with the regional geological map in the area compiled by alluvial deposits $(\mathrm{Q} a)$. Based on the resistivity, it has alluvial water dominated with depths ranging from $0.625-4.63 \mathrm{~m}$ below the surface, this is in accordance with the resistivity shown in Figure 7 with a light blue-purple image, stretching a total of 85 meters. The low resistivity is at 8.60-12.5 $\Omega \mathrm{m}$ which represents a water-saturated alluvial layer (Figure 7).

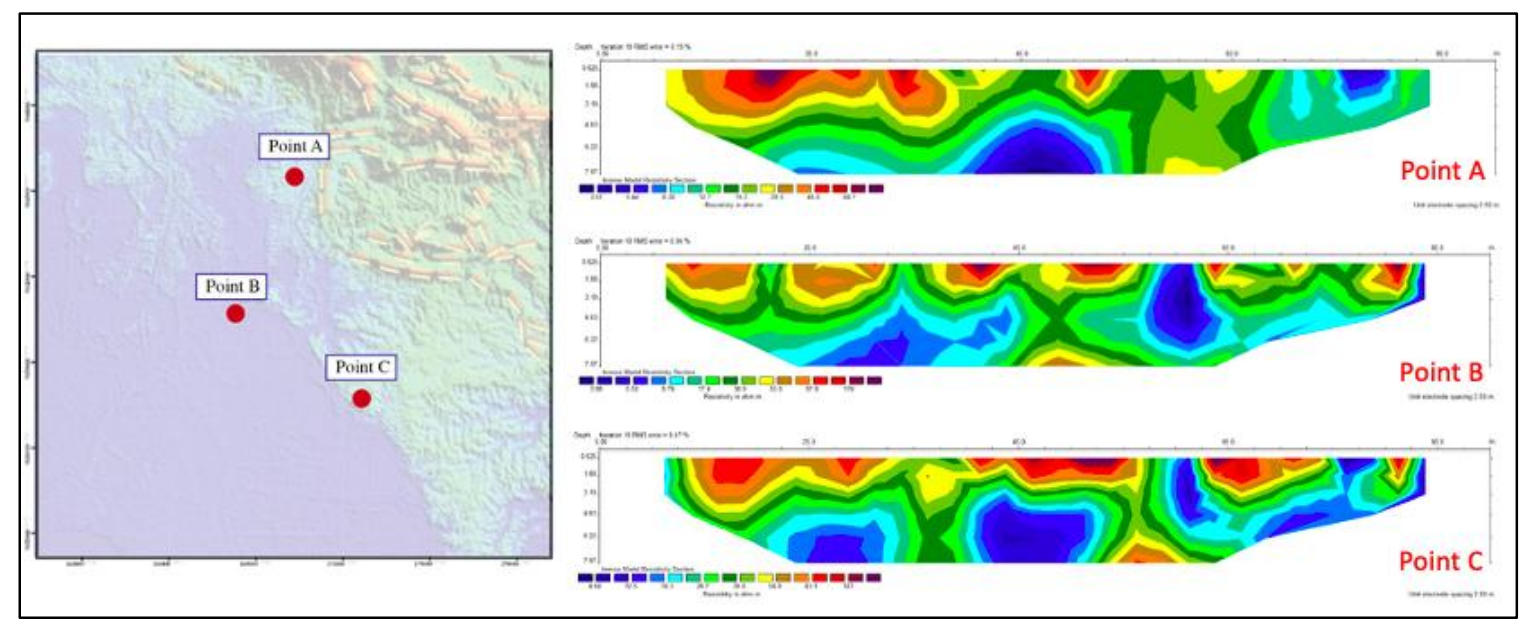

Fig. 7. The resistivity sections at points A, B and C. It shows the correlation of each measurement point to subsurface lithology. This is done to determine the depth of the water table and alluvial to the bedrock. In general, the three points have a uniform quaternary alluvial thickness pattern.

Table 2. Evaluation of the effect of liquefaction at the soil surface using the ratio of the thickness of the liquefiable layer and nonliquefiable layer obtained from the electrical resistivity survey. In general, points A, B, and C did not experience a significant difference in comparison, with the thickness of the liquefable layer being bigger than the non-liquefable layer.

\begin{tabular}{ccccc}
\hline Points & $\begin{array}{c}\text { Thickness of non-liquefiable layer } \\
\mathrm{H} 1(\mathrm{~m})\end{array}$ & $\begin{array}{c}\text { Thickness of liquefiable layer } \\
\mathrm{H} 2(\mathrm{~m})\end{array}$ & $\begin{array}{c}\text { Moderate } \\
\text { earthquake } \\
\mathrm{H} 2 / \mathrm{H} 1\end{array}$ & $\begin{array}{c}\text { Large } \\
\text { earthquake } \\
1.25 \mathrm{H} 2 / \mathrm{H} 1\end{array}$ \\
\hline $\mathrm{A}$ & 3.25 & 4.72 & 1.45 & 1.81 \\
$\mathrm{~B}$ & 3.20 & 4.77 & 1.49 & 1.86 \\
$\mathrm{C}$ & 3.71 & 4.26 & 1.15 & 1.43 \\
\hline
\end{tabular}

Table 2 shows the distribution of the thickness of the liquefied layer, associated with the alluvial presence with the water table. The distribution table is a summary of the resistivity plot described in the previous discussion. Thus, a simple method is applied to evaluate the risk of liquefaction using the thickness of the liquefied layer and the non-liquefied layer (Jinguuji and Toprak, 2017). Alluvial resistivity and water table determinations at points $\mathrm{A}, \mathrm{B}$ and $\mathrm{C}$ are related to the presence of a liquefable layer. It is estimated to be $\mathrm{H} 1$ (thickness of the non-liquefiable layer) and $\mathrm{H} 2$ (thickness of the liquefiable layer), and will be projected to the experimental data, derived from Jingunjii, 2017.

Based on the results of the thickness study, it can be seen that this study falls into the category of potential liquefaction in the large earthquake area due to the presence of the $\mathrm{H} 2$ value factor in the range of 4 meters and $\mathrm{H} 1$ in the range of 3 meters (Figure 8). This is in accordance with the 2017 Jiingunjii study which states that the influence factor in a large earthquake will cause liquefaction. 


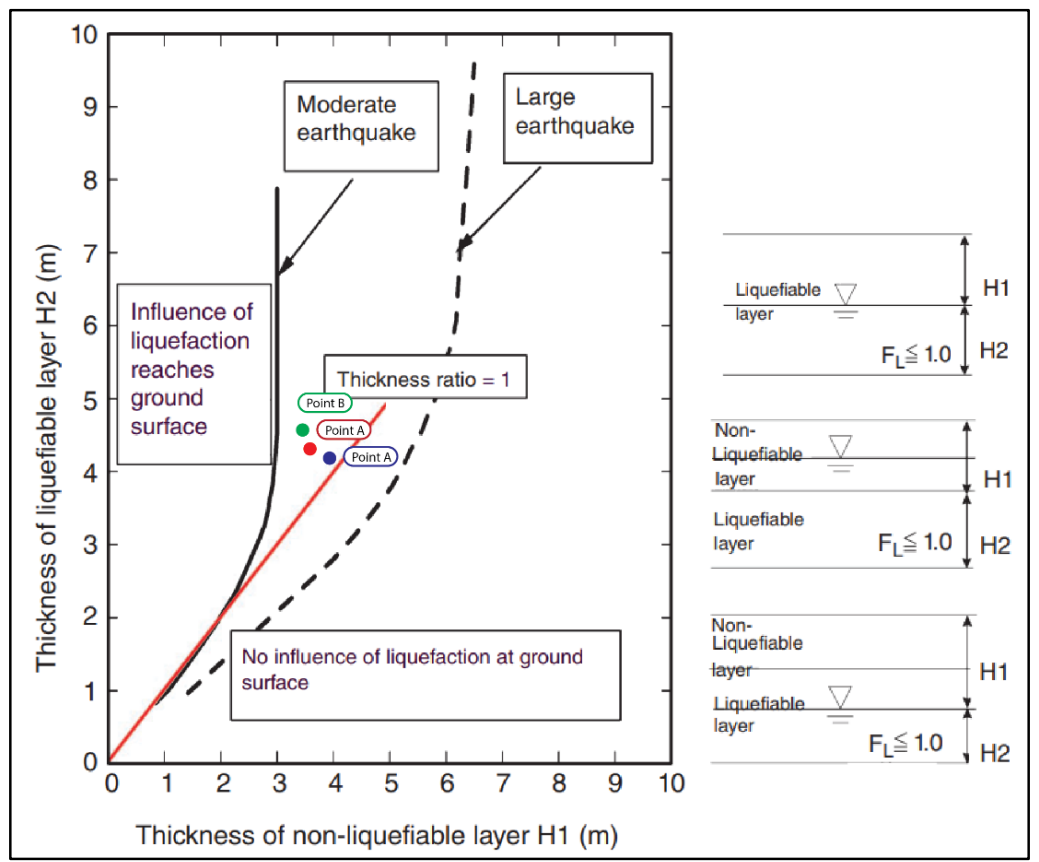

Fig. 8. Schematic curve of liquefable to non-liquefable layer based on Jingunji 2017 model. This research has overall thickness under the liquefable domination layer by having $4 \mathrm{~m}$ of thickness. Thus, indicates liquefable layer more dominant, resulting in potential lateral movement during the earthquake. This is congruent with the schematic model generated by Jingunjii while large earthquake plays an important role in inducing the liquefaction hazard.

\section{Conclusion}

This study concludes that integrated subsurface analysis using gravity and resistivity approaches greatly determines soil conditions that have the potential for liquefaction. This effect is based on the density distribution conditions of the residual anomaly and the thickness of the liquifable layer based on the 2D resistivity value.

Based on the gravity value, it was found that the distribution of the residual anomaly varies in all study areas. The maximum residual area is in the north west with a value of $115 \mathrm{MGal}$. In this area it is possible to have an uplift / basement high with a thin sediment thickness. As well as the existence of a fault with a northwest-southeast orientation with a significant contrast to the $115 \mathrm{MGal}$ and $45 \mathrm{MGal}$ anomalies. In the south, the gravity anomaly drops drastically in the range of 45 - $60 \mathrm{MGal}$ due to the presence of sedimentary basins and the presence of water-saturated alluvial deposits.

On the other hand, the results of the resistivity at points $\mathrm{A}, \mathrm{B}$ and $\mathrm{C}$ were in agreement with the resulting surface sediment thickness at $7.97-11 \mathrm{~m}$. This was then carried out by separating the dominant alluvial potential of saturated water, the result was $3-70 \Omega \mathrm{m}$. The results of this resistivity plot produce $\mathrm{H} 1$ models at a range of 3 meters and $\mathrm{H} 2$ at a range of $4 \mathrm{~m}$. So, it can be concluded that based on the Jingunji 2017 approach, this research is included in the potential liquefaction category with the potential for a large earthquake.

\section{Acknowledgements}

The author would like to thank to LPPM UNSOED, who gave fund for this research and the Western Australian Geodesy of Curtin University, Australia, for having GGMPlus data.

\section{References}

Aditama, M. R. et al. (2019) 'Structural framework and its compartmentalisation within the associated uncertainties: A case study from the Statfjord Reservoir, Northern North Sea', in Journal of Physics: Conference Series. doi: 10.1088/1742-6596/1367/1/012038.

Aditama, M. R., Saadi, A. G. and Nurcahya, B. E. (2020) 'Investigasi Kerentanan Tanah Berpotensi Likuifikasi Menggunakan Metode Mikroseismik Di Wilayah Prambanan, Yogyakarta', Dinamika Rekayasa. doi: 10.20884/1.dr.2020.16.2.323.

Van Bemmelen, R. W. (1949) 'The Geology of Indonesia. General Geology of Indonesia and Adjacent Archipelagoes', Government 
Printing Office, The Hague.

Daud, Y. et al. (2019) 'Resistivity characterization of the Arjuno-Welirang volcanic geothermal system (Indonesia) through 3-D Magnetotelluric inverse modeling', Journal of Asian Earth Sciences. doi: 10.1016/j.jseaes.2019.01.033.

FitzGerald, D. (2020) 'Improved 3D Geology Modelling using an Implicit Function Interpolator and Forward Modelling of Potential Field Data', in. doi: 10.3997/22144609-pdb.146.6.1.

Gao, F., Chen, H. B. and Luo, Y. (2013) '3D Sediment Physical Model Test Study for PLTU 2 JATENG $1 \times 660 \mathrm{MW}$ Adipala, Cilacap, Indonesia', in Springer Geology. doi: 10.1007/978-3-642-31671-5_19.

Guillen, A. et al. (2008) 'Geological modelling from field data and geological knowledge. Part II. Modelling validation using gravity and magnetic data inversion', Physics of the Earth and Planetary Interiors. doi: 10.1016/j.pepi.2008.06.014.

Hall, R. (2012) 'Late Jurassic-Cenozoic reconstructions of the Indonesian region and the Indian Ocean', Tectonophysics. doi: 10.1016/j.tecto.2012.04.021.

Hardy, T. et al. (2015) 'KARAKTERISTIK LAPISAN TANAH BERPOTENSI LIKUIFAKSI BERDASARKAN RESISTIVITAS BATUAN DI DAERAH CILACAP', Jurnal Meteorologi dan Geofisika. doi: 10.31172/jmg.v16i1.262.

Hirt, C. et al. (2013) 'New ultrahigh-resolution picture of Earth's gravity field', Geophysical Research Letters. doi: 10.1002/grl.50838.

Iswahyudi, S. et al. (2019) 'KONTROL STRUKTUR GEOLOGI PADA KEMUNCULAN MATA AIR PANAS BUMI DAERAH SUBANG, JAWA BARAT', Jurnal Geosaintek. doi: 10.12962/j25023659.v5i3.6237.

Jinguuji, M. and Toprak, S. (2017) 'A case study of liquefaction risk analysis based on the thickness and depth of the liquefaction layer using CPT and electric resistivity data in the Hinode area, Itako City, Ibaraki Prefecture, Japan', Exploration Geophysics. doi: 10.1071/EG16137.

Masson, F. et al. (2012) 'Lithospheric structure of Taiwan from gravity modelling and sequential inversion of seismological and gravity data', Tectonophysics. doi: 10.1016/j.tecto.2012.04.012

Muhaimin, M., Tjahjono, B. and Darmawan, D. (2016) 'ANALISIS RISIKO GEMPABUMI DI CILACAP PROVINSI JAWA TENGAH', Jurnal Ilmu Tanah dan Lingkungan. doi: 10.29244/jitl.18.1.28-34.

Nakata, N. and Snieder, R. (2014) 'Monitoring a building using deconvolution interferometry. II: Ambient-vibration analysis', Bulletin of the Seismological Society of America. doi: $10.1785 / 0120130050$.

Ozcep, F. and Ozcep, T. (2011) 'Geophysical analysis of the soils for civil (geotechnical) engineering and urban planning purposes: Some case histories from Turkey', International Journal of Physical Sciences. doi: 10.5897/IJPS11.090.

Pokhrel, R. M., Kuwano, J. and Tachibana, S. (2013) ‘A kriging method of interpolation used to map liquefaction potential over alluvial ground', Engineering Geology. doi: 10.1016/j.enggeo.2012.10.003.

Suwarno, Sutomo and Aditama, M. R. (2019) 'The analysis of the landslide vulnerability sub watersheds arus in banyumas regency', Geographia Technica, 14(2). doi: 10.21163/GT_2019.142.10.

Tini, T., Tohari, A. and Iryanti, M. (2017) 'Analisis Potensi Likuifaksi Akibat Gempa Bumi Menggunakan Metode SPT (Standar Penetration Test) Dan Cpt (Cone Penetration Test) Di Kabupaten Bantul, Yogyakarta', Wahana Fisika. doi: 10.17509/wafi.v2i1.7022.

Widiyantoro, S. et al. (2020) 'Implications for megathrust earthquakes and tsunamis from seismic gaps south of Java Indonesia', Scientific Reports. doi: 10.1038/s41598020-72142-z.

Zeng, H., Xu, D. and Tan, H. (2007) ‘A model study for estimating optimum upward-continuation height for gravity separation with application to a Bouguer gravity anomaly over a mineral deposit, Jilin province, northeast China', Geophysics. doi: 10.1190/1.2719497.

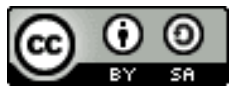

(C) 2021 Journal of Geoscience, Engineering, Environment and Technology. All rights reserved. This is an open access article distributed under the terms of the CC BY-SA License (http://creativecommons.org/licenses/by-sa/4.0/). 